\title{
Skin Incision-To Give or Not in Tracheostomy
}

\author{
Saroj Kumar Pattnaik
}

Indian Journal of Critical Care Medicine (2020): 10.5005/jp-journals-10071-23483

Sir,

I read with interest the article by Kumar et al. ${ }^{1}$ where the authors have suggested an innovation in tracheostomy procedure for decreased bleeding in coagulopathy patients.

The procedural innovation done by blunt dilation of the skin and subcutaneous tissues by the introducer of the guidewire and not giving incision over the skin and soft tissues might have resulted in lower bleeding complications during the procedure, but it may lead to major issues later after decannulation of the tracheostomy tube.

I want to share our center experience as we have done in a few cases as per the authors' innovation, which had decreased bleeding complications even in coagulopathy patients. ${ }^{2}$ But the invagination of skin into the tracheal wound during insertion of the tracheostomy tube due to small blunt dilation at skin level leads to nonhealing ulcer and/or granulation at the entry point, detected post-decannulation of the tracheostomy tube (Fig. 1).

This caused significant discomfort to the patient as there were discharges from the tracheostomy wound along with a nonhealing

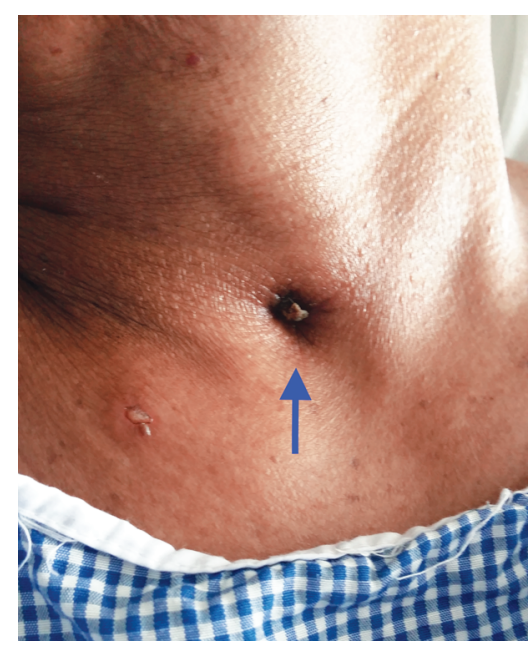

Fig. 1: Blue arrow showing skin invagination inside the tracheostomy wound post-decannulation (10 days after)
Department of Critical Care Medicine, Apollo Hospitals, Bhubaneswar, Odisha, India

Corresponding Author: Saroj Kumar Pattnaik, Department of Critical Care Medicine, Apollo Hospitals, Bhubaneswar, Odisha, India, Phone: +91 9439832424, e-mail: drsarojpatnaik@gmail.com

How to cite this article: Pattnaik SK. Skin Incision-To Give or Not in Tracheostomy. Indian J Crit Care Med 2020;24(7):601.

Source of support: Nil

Conflict of interest: None

ulcer, with or without bulging granulation tissue giving a deformed look to the wound.

As the skin invaginates inside the tract of tracheostomy, healing of the wound got hampered post-decannulation. Most of the cases needed a re-do of fresh incision of the skin around the tracheostomy wound, as opposed to the skin for healing, and also clearing of any granulation tissue, which then prompts healing but with an ugly scar left at the site.

Thus, to avoid migration of skin inside the tract, a small incision at the skin level will prevent the invagination of skin inside the tracheal wound, thus giving a nice cosmetic look at the tracheostomy site post-decannulation.

The small skin incision also makes a tight seal with the tracheostomy tube, thus putting a constant tamponade effect, hence reducing any capillary or venous bleeding.

\section{References}

1. Kumar P, Govil D, Patel SJ, Jagadeesh KN, Gupta S, Srinivasan S, et al. Percutaneous tracheostomy under real-time ultrasound guidance in coagulopathic patients: a single-center experience. Indian J Crit Care Med 2020;24(2):122-127. DOI: 10.5005/jp-journals-1007123344.

2. Pattnaik SK, Ray B, Sinha S. Griggs percutaneous tracheostomy without bronchoscopic guidance is a safe method: a case series of 300 patients in a tertiary care intensive care unit. Indian J Crit Care Med 2014;18(12):778-782. DOI: 10.4103/0972-5229.146303.

(-) The Author(s). 2020 Open Access This article is distributed under the terms of the Creative Commons Attribution 4.0 International License (https://creativecommons. org/licenses/by-nc/4.0/), which permits unrestricted use, distribution, and non-commercial reproduction in any medium, provided you give appropriate credit to the original author(s) and the source, provide a link to the Creative Commons license, and indicate if changes were made. The Creative Commons Public Domain Dedication waiver (http://creativecommons.org/publicdomain/zero/1.0/) applies to the data made available in this article, unless otherwise stated. 